\title{
Orígenes de la tesis sobre violencia política en el Chile de los sesenta y setenta. Un análisis de sus documentos fundantes
}

\section{Origins of the Thesis on Political Violence in Chile in the Sixties and Seventies. A analyzes of its founding documents}

\author{
Francisco Javier Morales Aguilera*
}

\begin{abstract}
Resumen: El periodo de transición a la democracia en Chile vio surgir como uno de sus productos más notables una perspectiva dominante y hegemónica sobre la compleja actuación de la izquierda en tiempos de la Unidad Popular. Una parte de esta explicación se articuló en torno a la denominada tesis sobre violencia política en los sesenta y setenta. El artículo plantea, sin embargo, que las bases conceptuales y temáticas de dicha tesis no fueron elaboradas en el periodo de la transición, sino que estos temas ya eran visibles en el contexto mismo del golpe de estado de 1973 en una serie de documentos y publicaciones provenientes del ámbito militar. Desde allí influirían decisivamente en sectores de la intelectualidad civil que adherían a la Dictadura, quienes contribuyeron a propagar, a través de diversas obras, la mencionada tesis.
\end{abstract}

Palabras claves Chile, violencia política, Fuerzas Armadas, Unidad Popular.

\begin{abstract}
The period of transition to democracy in Chile saw one of its most notable products emerge as a dominant and hegemonic perspective on the complex performance of the left in the times of Popular Unity. A part of this explanation was articulated around the denominated thesis on political violence in the sixties and seventies. The article proposes, however, that the conceptual and thematic bases of this thesis were not elaborated during the period of transition, but that these issues were already visible in the context of the 1973 coup d'état in a series of documents and publications coming from the military field. From there they would decisively influence sectors of the civilian intelligentsia that adhered to the Dictatorship, who contributed to propagate, through diverse works, the aforementioned thesis.
\end{abstract}

Keywords: Chile, political violence, Armed Forces, Popular Unity.

Recibido: 22 octubre 2018 Aceptado: 6 mayo 2019

\footnotetext{
* Chileno. Magíster en Historia Universidad de Santiago de Chile. Programa de Doctorado en Historia Contemporánea, Universidad Autónoma de Madrid. https:/ / orcid.org/0000-0002-3158-4948

Correo electrónico: franciscoj.morales@estudiante.uam.es
} 


\section{La construcción de la tesis sobre violencia política en el Chile contemporáneo. Ideas preliminares}

Escasos temas han logrado posicionarse tan hegemónicamente dentro del discurso oficial en Chile como el de la violencia política. Sobre todo, cuando este tipo de polémicas ha dejado de ser una disquisición meramente teórica y se remite a etapas, sujetos y escenarios específicos de nuestro pasado. En este sentido, la fase 1964-1973 se instala como el nudo contextual y temático más relevante, para ciertos autores, a la hora de caracterizar el tema de la violencia política en Chile.

Como es de suponer, las implicancias políticas e ideológicas contenidas en dicho argumento parcializaron en demasía los estudios a este respecto. Sin embargo, tales falencias no fueron advertidas como significativas por una parte importante de la elite dirigente encargada de conducir la transición a partir de 1990. Más bien, fueron asumidas como parte integrante de un relato histórico más o menos común respecto a la actuación de la izquierda antes de 1973.

El punto nodal de esta interpretación, a la luz de su vertiente historiográfica más representativa, radica pues en que la violencia política correspondió a una dinámica materializada, en los sesenta y parte de los setenta, exclusivamente por actores pertenecientes a la izquierda. De hecho y como una forma de reafirmar tales aseveraciones, algunas de estas investigaciones han indagado y resaltado desde aquellas prácticas específicas de violencia hasta lo que consideran sus soportes discursivos más representativos. ${ }^{1}$

Desde esta mirada, el proceder de las Fuerzas Armadas al derrocar el gobierno de la Unidad Popular no podría comprenderse si no se tenía en cuenta el contexto de violencia y polarización política previa al 11 de septiembre de 1973. Los militares, según esta visión, actuaron reactivamente frente a un clima de enfrentamiento que de no ponérsele fin habría significado un agudo enfrentamiento social y político entre sectores irreconciliables, uno de los cuales -aquel perteneciente a la izquierda- se encontraba fuertemente armado y dispuesto a eliminar físicamente a sus adversarios. Pues bien, la expresión más visible de este planteamiento -su punto de llegada en cuanto a elaboración y coherencia argumentativa- se alcanzaría tras el fin del Régimen Militar en la denominada tesis sobre violencia política en Chile. Sin embargo, sus orígenes conceptuales y temáticos, como veremos más adelante, se remontan a los años setenta en el contexto mismo de la crisis política de 1973: Allí están lo que a nuestro juicio constituyen sus documentos fundantes más representativos.

Antes de revisar dicho material, conviene analizar los puntos sustantivos de la mencionada tesis. Como sabemos, sería en el Informe de la Comisión de Verdad y Reconciliación de 1991 en donde quedó explicitado el planteamiento que veía en la década

\footnotetext{
${ }^{1} \mathrm{Al}$ menos tres textos logran sintetizar de buena forma los énfasis fundamentales de esta perspectiva: Patricia Arancibia, Los orígenes de la violencia política en Chile. 1960-1973, Santiago, Universidad Finis Terrae- Instituto Libertad y Desarrollo, 2001. También de Patricia Arancibia junto a María de los Ángeles Aylwin y Soledad Reyes, Los hechos de violencia en Chile: del discurso a la acción, Santiago, Universidad Finis Terrae-Instituto Libertad y Desarrollo, 2003, y Adolfo Ibáñez, Abrazado por la revolución: ideología y totalitarismo en Chile. 19601973, Santiago, Biblioteca Americana, 2004.
} 
del sesenta y setenta un ciclo latente de violencia política y extrema radicalización, cuyos principales promotores y a la larga responsables directos fueron aquellos actores provenientes de la izquierda. ${ }^{2}$ Dichos énfasis constituían el telón de fondo sobre el cual se debía entender la actuación posterior de las Fuerzas Armadas. ${ }^{3}$

Recordemos que la Comisión Nacional de Verdad y Reconciliación respondió a una iniciativa directa del Presidente Patricio Aylwin tras asumir la Presidencia en marzo de 1990. El objetivo fundamental de esta Comisión consistiría en elaborar un informe relativo a las violaciones a los Derechos Humanos ocurridas en Dictadura a fin de que el país pudiera formarse un "concepto racional y fundamentado" sobre lo ocurrido. ${ }^{4}$ En este sentido, la Comisión confeccionaría un completo cuadro sobre dichas violaciones, centrándose en aquellos casos con resultado de muerte y desapariciones cometidas por agentes del Estado, o particulares, con fines políticos durante el Régimen Militar.

Dicho registro, sin embargo, sería precedido de un extenso marco históricopolítico, redactado por el abogado e historiador Gonzalo Vial Correa, el cual comprendía dos grandes fases de estudio. La primera de ellas se refería a la situación imperante en el país al 11 de septiembre de 1973, mientras que la segunda, se enfocaba en el periodo 19731990. En la primera fase, Vial explicitaría la tesis que veía en la década del sesenta y setenta un periodo marcado por la violencia política. Cabe precisar en todo caso que la mencionada tesis, con sus respectivas ideas y utillaje conceptual, ya se había comenzado a esbozar, con cierta claridad, apenas ocurrido el golpe militar. De hecho, el trabajo de redacción que el propio Gonzalo Vial realizó en el cuestionado Libro Blanco del cambio de Gobierno en Chile -cuya autoría reconocería recién en 1999- constituye un antecedente clave en este sentido, toda vez que allí se articularon los argumentos más significativos sobre el supuesto carácter violentista de la izquierda chilena en tiempos de la Unidad Popular. ${ }^{5}$ Se trata, pues, de dos marcos contextuales que en realidad no difieren sustantivamente a la hora de atribuir responsabilidades específicas sobre el origen de la violencia en Chile antes del golpe militar.

Cabe precisar que, junto a los elementos arriba descritos, el Informe de la Comisión de Verdad y Reconciliación remarca dos líneas de análisis respecto a la tesis explicitada. En primer término, que los procesos de polarización y conflictividad política vividos en el mundo a partir de la Guerra Fría constituyeron un antecedente decisivo en la sobreideologización de ciertos actores locales en el transcurso de la década del sesenta. A partir de estas coordenadas, los movimientos de izquierda fueron los primeros en absorber el ethos rupturista de aquel entonces, adscribiendo plenamente a los énfasis que mostraban a la vía armada como un camino factible y atractivo de seguir.

\footnotetext{
2 La emergencia de este tipo de discursos en el contexto del Golpe Militar del 11 de septiembre y su vinculación a una memoria histórica colectiva de compleja proyección ha sido analizada por Steve Stern, Luchando por mentes y corazones. Las batallas de la memoria en el Chile de Pinochet, Santiago, Universidad Diego Portales, 2013. En especial, véase el capítulo 2. Informe de la Comisión Nacional de Verdad y Reconciliación, Santiago, 1991, Vol. I, pp. 34-39.

3 Tal énfasis también sería recogido en el documento final de la denominada Mesa de Diálogo que convocó a sectores civiles y militares, hacia fines de los noventa, en torno a los temas de derechos humanos aún abiertos. Véase, Hacia el reencuentro de todos los chilenos. Acuerdo de la Mesa de Diálogo. Gobierno de Chile, junio de 2000.

4 Informe, op. cit., Vol. I, p. III.

5 La columna de Gonzalo Vial donde reconoce dicha autoría fue publicada en el vespertino La Segunda, Santiago, 2 de febrero de 1999, p. 8.
} 
La segunda línea de análisis se refiere a la existencia de una etapa de agudización del conflicto político a partir de la llegada de la UP al gobierno en 1970. En efecto, la aplicación de un programa que buscaba transitar hacia un estado socialista generaría situaciones de abuso y descontrol (expropiaciones, ocupaciones ilegales, "tomas", huelgas, etc.) por parte del Estado y de las bases militantes que apoyaban al gobierno. Todo ello conformaría un cuadro de extrema polarización y conflictividad político-social que abriría paso a la intervención militar del 11 de septiembre de 1973. Es decir, la actuación de las Fuerzas Armadas debe entenderse desde un punto de vista reactivo a una situación de descontrol y caos que el gobierno de la UP había contribuido a generar. Es en este plano argumental en donde se mueve, pues, la totalidad de la tesis sobre violencia política en Chile; un plano que visualiza este problema como un fenómeno de origen preciso, fechada dentro de un marco regional y mundial de extrema complejidad y con actores claramente reconocibles y, por cierto, responsables de lo sucedido.

\section{Algunas coordenadas bibliográficas}

En este punto de la exposición resulta interesante constatar cómo entre fines de los noventa y los primeros años del siglo XXI, una serie de textos complementarían los énfasis y el carácter fundamental de la mencionada tesis. Los ya citados trabajos de Patricia Arancibia y Adolfo Ibáñez, por ejemplo, caracterizaron críticamente el comportamiento y fervor revolucionario que se desarrolló en buena parte de la izquierda chilena a la luz de sus premisas discursivas y acciones más relevantes. El registro detallado de todo cuanto dijo la izquierda en aquel entonces representaría, en el caso de Arancibia, una prueba irrefutable de su tendencia casi natural por la violencia y el extremismo. Ibáñez, en tanto, consideraría que al mediar los sesenta, y a la luz del ideologismo dominante, se iniciaría un ciclo latente de guerra civil, el cual se materializaría plenamente bajo la Unidad Popular.

Con énfasis similares a los arriba descritos pueden ubicarse algunos textos de menor repercusión, pero que de todas formas contribuyeron a sustentar y amplificar esa mirada en torno a las responsabilidades de la izquierda chilena en el desarrollo de la violencia política. Se trata de algunos libros y ensayos periodísticos publicados, al igual que en los casos anteriores, entre fines de los noventa y primeros años de la década del 2000. Entre los libros, destaca la crónica testimonial de Alberto León, Tiempo Rojo y el

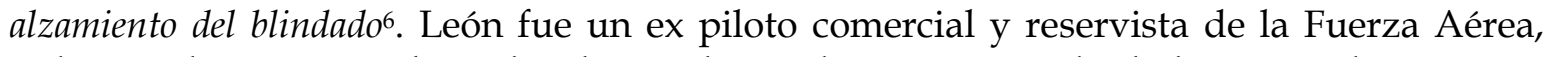
militante de Patria y Libertad y destinado en el Regimiento Blindado No2 en la época en que dicha unidad se sublevó en contra del gobierno de Allende en junio de 1973. Aparentemente se trataría de un texto valioso en virtud de la experiencia personal del autor, sin embargo, la mirada maniquea que dejan traslucir sus páginas, en donde la izquierda chilena es vista como una alianza totalitaria y dispuesta a eliminar sin consideración a sus oponentes, enceguece la totalidad de la reflexión.

${ }^{6}$ Alberto León, Tiempo Rojo y el alzamiento del blindado, Santiago, 1999. 
Desde la prensa escrita destacaría un largo ensayo publicado por José Piñera en El Mercurio en agosto de 2003.7 Se trataría, como es de suponer, de un texto que entiende el problema del quiebre institucional de 1973 a partir de las responsabilidades históricas de la izquierda chilena. A lo largo de sus páginas, el análisis y los puntos de vista del autor se van complementando con una serie de citas y declaraciones provenientes de los partidos y figuras más connotadas de la Unidad Popular y de la clase política en general. Todo lo anterior se realiza con el fin de demostrar lo que a estas alturas es un lugar común dentro de este tipo de interpretaciones, a saber: que la izquierda tuvo una predisposición natural por la violencia y el extremismo, por lo que la intervención de las Fuerzas Armadas resultaba inevitable, y más aún necesaria, a objeto de derribar la amenaza comunista que representaba el gobierno de la UP.

Desde el mundo militar se estableció una mirada similar sobre el tema. A decir verdad, la perspectiva de este sector mantenía una línea de análisis casi inalterable en el tiempo, la cual enfatizaba en el carácter violentista de la izquierda chilena en contraposición al proceder patriótico de las Fuerzas Armadas. En algunos casos podía observarse una mayor extensión cronológica para abordar este fenómeno, pero siempre bajo la matriz interpretativa que le era característica. Este fue el caso del estudio de los oficiales Carlos Molina y Francisco Balart Páez, La violencia política en Chile. ${ }^{8}$ El punto de arranque de este texto busca cuestionar la idea en torno a que Chile es un país con una trayectoria cívica regulada por la paz y el derecho, pues la violencia, sobre todo aquella de carácter política, ha perturbado históricamente la convivencia nacional. Así, el análisis histórico de esta problemática se encuentra dividido en tres etapas. La primera denominada violencia revolucionaria, que abarca desde la guerra civil de 1891 hasta el gobierno de Jorge Alessandri al mediar el siglo XX; la segunda etapa es definida como de violencia subversiva y abarca las administraciones de Eduardo Frei Montalva y Salvador Allende. La última fase corresponde a la denominada violencia terrorista, entendida como un producto concebido conceptualmente en la Unión Soviética, dirigida estratégicamente desde Cuba y materializada, en Chile, por aquellos grupos afines al marxismo. Su extensión sería hasta 1995.

Desde una perspectiva similar, aunque enfocándose en un periodo de tiempo más acotado, el otrora jefe supremo de la Dirección de Inteligencia Nacional de Chile (DINA), general Manuel Contreras Sepúlveda, publicó el libro La verdad histórica. El Ejército Guerrillero. ${ }^{9}$ En dicho texto, Contreras recopila, detallada y exhaustivamente, una amplia cronología de hechos de connotación violentista ocurridos en Chile entre 1967 y 1973, periodo en que, bajo su óptica, actuó el "Ejército Guerrillero": una denominación genérica para referirse a los grupos e individuos que, en su opinión, abrazaron el camino de las armas en esos años. Por cierto, se trata de un texto cuyo propósito principal es justificar las violaciones a los derechos humanos ocurridas después del golpe militar de septiembre de 1973, toda vez que las acciones de violencia fueron iniciadas por la izquierda y sus grupos

\footnotetext{
7 José Piñera, "Nunca Más. Un ensayo sobre el quiebre de la democracia en Chile". El Mercurio, Santiago, 24 de agosto de 2003, Cuerpo de Reportajes, pp. 11-13.

${ }^{8}$ Carlos Molina y Francisco Balart, La violencia política en Chile, Santiago, Biblioteca Militar, 1999.

${ }_{9}^{9}$ Manuel Contreras, La verdad histórica. El Ejército Guerrillero, Santiago, Encina, 2000.
} 
más activos, situación que las Fuerzas Armadas no podían tolerar por lo que se vieron necesariamente obligadas a actuar.

En el conjunto de las obras arriba reseñadas, es posible advertir una mirada parcial, y más aún tributaria de una lógica mayor, a saber, entender las transformaciones de los últimos cuarenta años en Chile a partir de las responsabilidades políticas, y por qué no históricas, de un sector especifico de la sociedad chilena. Dicho actor, en virtud de sus discursos y acciones estratégicas, generó las condiciones necesarias para que las FFAA -impolutas bajo esta mirada de cualquier rasgo de extremismo- intervinieran a fin de modificar el curso de los acontecimientos. En el transcurso de estas modificaciones, según estos autores, se generaron abusos que no responderían a lógicas internas preexistentes sino más bien a respuestas coyunturales derivadas del clima de violencia política que otros actores generaron. De este modo, el problema de la violencia quedaba resituado no a partir del golpe militar de 1973 sino de su etapa previa producto de la activa movilización social y el extremismo de algunos discursos y comportamientos desarrollados por la izquierda. Así, una parte no menor de la memoria histórica de nuestro pasado reciente quedaba enclaustrada dentro de esquemas historiográficos que condicionaban el problema de la violación de los derechos humanos al conocimiento de un contexto previo que permitiera una comprensión cabal del fenómeno, cuando no la justificación implícita de esas violaciones.

Distanciándose de los enfoques hasta aquí señalados se sitúa la obra de Gabriel Salazar, La violencia política popular en las "Grandes Alamedas"10. Su texto, claro está, no sólo guarda diferencias ideológicas sustantivas respecto a los autores ya consignados, sino que también se trata de diferencias metodológicas y hermenéuticas fundamentales a la hora de entender el problema de la violencia política en Chile. Desde ya Salazar comprende este tópico a partir de la compleja relación de las clases populares respecto a las elites dirigentes, en un juego dialéctico de permanente tensión y contradicciones de orden ideológico y material. La perspectiva cronológica de este autor, que se remonta hasta la conformación misma del estado nación en el siglo XIX, no es una cuestión trivial, pues junto a la evolución institucional del país se fueron desarrollando ciclos y escenarios particulares de violencia política popular, la mayoría de los cuales tuvo como causa fundante el despliegue y materialización de una represión de tipo estatal. Así entonces, aquella violencia correspondiente a la década del sesenta y parte de los setenta no puede entenderse de forma separada o segmentada. Tal periodo, inserto dentro de la fase 19431973, es uno más dentro de una cadena amplia de ciclos y contra-ciclos de lucha política popular.

Mirado en su conjunto, la propuesta de Salazar no entiende el fenómeno de la violencia política a partir de sus coordenadas institucionales, ni tampoco como una expresión de anomia social que resquebraja la estabilidad y el orden. Las directrices sistémicas, los canales y prácticas más cotidianas de "la política" (en el sentido formal del término) no guardan mayor relación con las expresiones de descontento popular. De tal manera entonces, visualizar la violencia política en clave institucional (como lucha de proyectos, desborde, inestabilidad o polarización del sistema) revelaría una parte mínima

10 Gabriel Salazar, La violencia política popular en las "Grandes Alamedas", Santiago, Lom, 2006 [primera edición, 1990]. 
del fenómeno y en ningún caso sus complejidades más intrínsecas. En este marco, el texto de Salazar difícilmente podría dialogar con aquellas otras obras reseñadas aquí, pues sus énfasis se alejan de la contingencia y de los marcos contextuales en que todo parece estar suficientemente explicitado y predefinido respecto a los responsables de la violencia política.

Ante todo, la obra de Salazar invita a reflexionar en torno a una lectura crítica del problema, constituyendo claramente una excepción dentro del mundo intelectual de la izquierda chilena, siempre tan reacia a abordar este tipo de fenómenos. Es posible pensar, en esta línea, que la ausencia de estudios provenientes desde el mundo académico de la izquierda dejó el campo abierto para que sectores militares y civiles hegemonizaran rápidamente el debate y los tópicos más representativos sobre la violencia política en Chile, logrando sintetizar una mirada unidireccional sin desvíos ni contrapesos de importancia como para redefinir los marcos interpretativos con que se analizaba el fenómeno.

\section{Problemas anexos y estructura argumental}

La complejidad de este problema no parece ser en todo caso exclusiva de Chile, pues en otros países del cono sur que igualmente atravesaron por experiencias de quiebre institucional e instauración de dictaduras militares se pudieron observar intentos por reinterpretar el pasado a partir de las responsabilidades políticas que les cabía a ciertos actores. En el espacio rioplatense esta discusión se sintetizó en torno a la denominada teoría de los dos demonios, explicitada aparentemente en el prólogo del Informe Nunca Más de la CONADEP11. Tal teoría entendía el problema de la violencia política como una responsabilidad de dos fuerzas antagónicas (guerrilla y fuerzas armadas) que actuaron en grados y profundidades similares entre las décadas del sesenta y setenta. Bajo esta mirada, la violencia quedaba resituada como un fenómeno continuo en donde las fronteras entre el accionar de uno y otro bando quedaban completamente desdibujadas.

Para Elizabeth Jelin, sin embargo, la teoría de los dos demonios surgió a partir de una lectura equivocada del Informe de la CONADEP, pues a su juicio lo que allí se expresaba era el desarrollo de una "escalada de violencias", es decir, una de carácter guerrillero que despertó a otra de corte militar ${ }^{12}$. El problema en ambos casos, acota Jelin, es que la violencia, entendida en términos de acción/reacción, quedaría condicionada por la incómoda pregunta de quién empezó todo, retrotrayendo así el análisis hacia un punto de partida indeterminado ${ }^{13}$.

En el caso específico de Uruguay, apunta Carlos Demassi, la teoría de los dos demonios fue asumida casi a plenitud por amplios sectores de la elite política e intelectual de ese país alcanzando incluso una circulación importante entre buena parte de la opinión

\footnotetext{
11 Comisión Nacional sobre la Desaparición de Personas, Nunca Más, Buenos Aires, Eudeba, 1986.

12 Elizabeth Jelin, "Militantes y combatientes en la historia de las memorias: silencios, denuncias y reivindicaciones", Meridional, N 1, octubre 2013, p. 89.

13 Idem.
} 
pública14. Para Demassi, la mencionada teoría se situó como un corolario natural de la lucha antisubversiva llevada a cabo por las fuerzas armadas en contra de los tupamaros, lo que de paso significaba una crítica abierta hacia la clase política de entonces por permitir el surgimiento del brote guerrillero. Adicionalmente, acota el autor, dicha teoría pasó a ser la explicación oficial del gobierno en el periodo de la transición a la democracia, lo que permitía personificar y al mismo tiempo delimitar bien a ambos demonios: la sedición guerrillera y los militares golpistas ${ }^{15}$.

En virtud de lo anterior, cabe preguntarse si resulta equiparable la teoría de los dos demonios a la tesis sobre violencia política en el Chile de los sesenta y setenta. Preliminarmente habría que aclarar que ambas interpretaciones, independiente de sus deficiencias y objetivos, responden a contextos y situaciones históricas particulares, con actores, coyunturas y escenarios bastante disímiles entre sí. Sin embargo, creemos que el punto de comunión entre ambas explicaciones está dado en virtud de su necesidad por responsabilizar fácticamente a ciertos actores -casi siempre de izquierda- por los hechos de violencia ocurridos, de modo que el accionar uniformado sea visto como un comportamiento reactivo frente a una situación apremiante y crítica que "otros" decantaron en el seno de cada sociedad.

La continuación natural de este argumento es la justificación implícita de las violaciones a los derechos humanos cometidas por los militares tras su acceso al poder, pues dichos eventos habrían sido motivados por una contingencia mayor que obligó al mundo castrense a proceder de esa forma en pos de un bien mayor. Bajo ese marco, la violencia guerrillera, e inclusive la que fue enarbolada tan solo discursivamente por la izquierda, quedaba en un estado de salvajismo y procacidad mucho mayor que aquella uniformada, inclinando así la balanza respecto a qué violencia resultaba a la larga más dañina y peligrosa. El punto central de ambos planteamientos no era entonces desconocer lo obrado por las fuerzas armadas, sino sopesar cuál de las dos violencias fue primero y por ende más determinante para así explicar -y a la larga justificar- el surgimiento de la otra.

Volviendo al curso central de nuestra propuesta, el objetivo de este artículo es analizar las fuentes y documentos que dieron origen a la tesis sobre la violencia política en el Chile de los sesenta y setenta y que aparecieron tempranamente tras el golpe militar. No se debe olvidar que el marco contextual del Informe Rettig no fue más que una continuación natural de una interpretación que ya se había elaborado por parte del mundo militar a efectos de justificar el golpe de estado. Debemos advertir, además, que el énfasis no está puesto en las dinámicas concretas de violencia política que eventualmente sucedieron a lo largo de ese periodo, sino más bien en cómo dicho fenómeno fue interpretado y trabajado tras el golpe militar hasta transformarlo en un discurso proyectualmente hegemónico y coherente a las dinámicas socio-políticas de los últimos treinta años. En este sentido, diversos documentos y trabajos fueron adscribiendo con el paso del tiempo a esta línea de análisis, contribuyendo así en visibilizar aún más la

\footnotetext{
14 Carlos Demassi, “Ante la teoría de los dos demonios ¿cuáles dos demonios?” columna de opinión publicada en: http://www.paginadigital.com.ar/articulos/2003/2003quint/noticias18/1204711-7.asp, acceso, 20-092017.

$15 \mathrm{Idem}$
} 
mencionada tesis, definiendo con precisión el rol de sus protagonistas y las responsabilidades que le cabían a cada uno de ellos. Nuestra metodología de trabajo consiste en analizar el contenido de dichos textos, sus temáticas más recurrentes, sus constructos conceptuales e inclusive su material fotográfico a efectos de verificar y mostrar cómo sus énfasis y argumentos son plenamente coincidentes y subsidiarios de aquella matriz interpretativa que, sobre la violencia política en Chile, elaborasen las Fuerzas Armadas.

El planteamiento central de este artículo sostiene que la temática sobre la violencia política en Chile durante los sesenta y setenta fue tempranamente abordada por el gobierno militar como una forma de justificar la intervención y actuación de las Fuerzas Armadas en el marco del quiebre institucional de 1973, observándose una línea conceptual y metodológica bastante nítida en diversas fuentes y documentos. En lo que respecta a la tesis misma, aquella no tiene su origen, como podría pensarse, en el marco contextual que el historiador Gonzalo Vial redactó para el Informe Rettig en 1991. Dicho marco, con su tesis allí explicitada, fue el punto de llegada de una concepción e interpretación particular que sobre el tema de la violencia política se venía esbozando ya desde la primera mitad de los setenta por parte del mundo militar.

Junto a los elementos arriba señalados, resulta pertinente esbozar algunas directrices en torno a las fuentes utilizadas en este trabajo. Como se podrá advertir, en la primera parte se utilizan fundamentalmente fuentes documentales y periódicas provenientes desde las Fuerzas Armadas. Existe, en este sentido, una detención mayor en la que creemos constituye una de las obras más representativas en la configuración y posterior divulgación de la tesis sobre violencia política: el Libro Blanco del Cambio de Gobierno en Chile. En efecto, se trata de un documento polémico, ampliamente criticado, pero que resultaba inevitable abordarlo para los objetivos de este artículo, aunque fuese desde su propia complejidad. Porque a pesar de las críticas y déficits que diversos cientistas sociales han hecho notar respecto al Libro Blanco, éste tuvo una proyección importante tanto en el mundo militar como en diversos círculos intelectuales y de la sociedad civil.

El segundo grupo de fuentes utilizadas en esta primera parte corresponde a publicaciones periódicas emanadas desde las diversas ramas de las Fuerzas Armadas. Eventualmente, podría discutirse el impacto y alcance que tuvieron dichas publicaciones en cuanto a su capacidad de influir en el debate público. Si bien se trató en su mayoría de un material que circulaba dentro de las reparticiones uniformadas, no es menos cierto que su contenido se divulgaba, en general, dentro de todo el escalafón. Además de ello, la temática sobre la violencia política no quedó reducida exclusivamente al mundo militar, pues ella también fue abordada por diversos sectores de la intelectualidad civil quienes, adscribiendo plenamente a su lógica interna, contribuyeron en divulgar esta problemática. Nos referimos a la denominada perspectiva civil, abordada en la segunda parte de este artículo. Como se advertirá, se trató de textos de corte periodístico y testimonial que fueron plenamente subsidiarios de los énfasis uniformados respecto al problema de la violencia política. Su originalidad, en efecto, es casi nula pues la mayoría de ellos toma al Libro Blanco como punto de referencia a la hora de documentar sus afirmaciones. Con todo, se trata de fuentes ineludibles a la hora de entender el impacto que tuvo la problemática sobre la violencia política dentro de diversos sectores de la sociedad chilena. 
Adicionalmente, cabría señalar que algunas de estas publicaciones han sido en general poco trabajadas por la historiografía nacional, ya sea porque se desconocía su existencia, o bien, porque se creía que su marcado sesgo ideológico oscurecería a tal punto el análisis que su contenido no constituía, en la práctica, un material digno de estudiarse.

En cuanto a su estructura, este artículo se divide en tres partes. La primera de ellas analiza los textos más representativos que desde el mundo uniformado contribuyeron a configurar, al menos en su núcleo originario, la tesis sobre violencia política en el Chile de los sesenta y setenta. En segundo término, se indaga, aunque de forma acotada, en aquellos textos que desde la óptica civil abordaron este tema, los cuales se nutrieron evidentemente de la perspectiva militar para desarrollar sus reflexiones. Se trató en definitiva de lecturas subsidiarias de la matriz uniformada que tan tempranamente había instalado el tema de la violencia política a fin de justificar el golpe militar. El texto finaliza con el planteamiento de algunas ideas e interrogantes generales que permitan entender el posicionamiento hegemónico de la mencionada tesis.

\section{Los orígenes de la tesis sobre violencia política en el Chile de los sesenta y setenta. La perspectiva militar}

En la mañana del 11 de septiembre de 1973, los primeros Bandos de la Junta Militar de Gobierno ya esbozaban tácticamente el tema de la violencia, en especial aquella que se vinculaba directamente al derrocado gobierno socialista. El bando $\mathrm{N}^{\circ} 3$, por ejemplo, advertía a la población que no se dejara llevar por incitaciones a la violencia emanadas desde "activistas nacionales o extranjeros", puesto que estos últimos, según la óptica militar, debían entender en Chile no se aceptaban "actitudes violentistas". ${ }^{16}$ Por su parte el bando $\mathrm{N}^{\circ} 5$ junto con responsabilizar al depuesto gobierno por fomentar "artificialmente una lucha de clases... llevando [al país] a una lucha fratricida" recalcaba como dichos antecedentes, es decir la violencia desatada por el régimen de la UP, amenazaban gravemente la seguridad interna y externa de la nación. ${ }^{17}$ Desde el mundo militar, la violencia constituía no sólo una práctica recurrente en aquellos miembros y adherentes del derrocado gobierno, sino que además, la irresponsabilidad de estos mismos sujetos al fomentar y manifestarse públicamente en favor de prácticas violentistas, había creado un clima de tal inseguridad que ya no solo los cimientos institucionales del país estaban erosionados, sino también la soberanía e integridad externa de la nación. Así, la violencia no solo adquiría una dimensión problemática de índole doméstica, sino que también podía constituirse en un factor de desestabilización regional e inclusive mundial.

Cuatro días después del golpe militar, el 15 de septiembre, la Junta de Gobierno dio a conocer un texto, a través de la Revista Aquí Está, en donde se reafirmaba que el accionar de las Fuerzas Armadas respondía a un clamor reiterado y multitudinario de las grandes mayorías nacionales en orden a poner a fin al caos, miseria y odio que reinaban en el país. En esa misma línea, la declaración sostenía que gracias al proceder uniformado la

16 Bandos de la Junta Militar de Gobierno. 11 de septiembre de 1973. Publicados íntegramente en El Mercurio, Santiago, 26 de septiembre de 1973, pp. 22 y 23.

17 Idem. 
patria se había liberado de los "malos chilenos que, fanatizados por la prédica de mercenarios extranjeros puestos al servicio del marxismo internacional pretendían hacer de Chile un país de esclavos... Se acabaron -continuaba el texto- los temores, los sectarismos, las prédicas de odio y los atentados contra la dignidad del chileno."18 El énfasis de esta declaración visualizaba, maniqueamente, que la maldad y el odio eran representados por actores específicos (en este caso pertenecientes a la izquierda) que se situaban en las antípodas del proceder patriótico y abnegado de las Fuerzas Armadas. Así, esta delimitación servía no solo para dejar en claro el papel que jugaron sus principales actores (buenos versus malos), sino que además reafirmaba la condición de no chilenos de aquellos sujetos partidarios de la izquierda. Tal perspectiva de análisis sería un recurso que como vimos más arriba, se volvería a reafirmar décadas después, en el texto del ex director de la DINA Manuel Contreras.

\section{El Libro Blanco del cambio de gobierno en Chile: Texto clave en la construcción de la tesis sobre la violencia política en Chile}

A pesar de los énfasis con que se intentó justificar del golpe militar, los documentos arriba señalados se revelarían, en la práctica, como insuficientes. Desde ya resultaban acotados a un evento muy coyuntural por lo que carecían de la suficiente profundidad para visualizar el tema de la violencia desde un marco más amplio. Ante ello, surgiría la necesidad de difundir un trabajo de mayor envergadura, en un formato distinto al de un bando militar o al de una revista, y en donde se pudieran exponer "documentadamente" los supuestos planes que preparaba el gobierno de Allende a fin de acabar con la institucionalidad y así obtener el poder total. Todo lo anterior debía entenderse en la perspectiva de que para las nuevas autoridades resultaba imperativo legitimar el golpe militar no solo al interior del país, sino también en el exterior. Este fue el contexto, pues, que daría forma a una de las publicaciones oficiales más controvertidas tras el golpe militar: el Libro Blanco del cambio de Gobierno en Chile. ${ }^{19}$ Revisemos algunos de sus antecedentes.

Apenas derrocado el gobierno de la UP, miembros de la Armada contactarían a diversos civiles a quienes se les mostró algunos documentos secretos hallados, según se les indicó, en distintas dependencias públicas. Dichos documentos demostraban la existencia de un supuesto plan estratégico (el Plan Z) mediante el cual la UP, vía autogolpe, tomaría el poder total en el país. En la práctica, dicho plan suponía la eliminación física de una gran parte de los opositores al gobierno y el descabezamiento de las principales instituciones armadas, objetivo que se materializaría entre el 17 y el 19 de septiembre de 1973, en el marco de la celebración de las glorias del Ejército. Se trataría, en fin, de una ofensiva violentísima por parte de la izquierda a fin de despejar el camino para la instauración de un régimen marxista totalitario. Los civiles contactados fueron mandatados entonces para escribir, en pocos días, un texto que expusiera dichos

\footnotetext{
18 Proclama de la Junta Militar de Gobierno, en Revista Aquí Está, Nº 70, Santiago, 28 de septiembre de 1973., $\mathrm{s} / \mathrm{p}$.

19 Libro Blanco del cambio de gobierno en Chile. 11 de septiembre de 1973. Secretaría General de Gobierno (Santiago, Editorial Lord Cochrane, 1973) [2ª edición]. En adelante se le mencionará simplemente como Libro Blanco.
} 
antecedentes bajo formato de libro, contribuyendo así en la justificación, nacional e internacional, del golpe militar. Tal fue el origen más inmediato del Libro Blanco.

Hasta el día de hoy, la mayor parte de los investigadores consideran que el mencionado Libro Blanco y la documentación allí consignada fueron parte de una operación comunicacional tendiente a falsificar los hechos con el objetivo de justificar el golpe militar. Según las autoridades de la época, gran parte de los documentos publicados fueron encontrados en dependencias del palacio presidencial de La Moneda, en las bóvedas del Banco Central y en diversas sedes políticas de los partidos de izquierda. Sin embargo, los documentos originales nunca han sido dados a conocer por ninguna de las autoridades de la época. El historiador Gonzalo Vial, uno de los autores confesos de este texto $-\mathrm{y}$, recordemos, redactor del marco contextual del Informe Rettig de 1991-, no ha informado que sucedió posteriormente con dichos papeles. Solo se ha podido acceder a las copias que entrega el mismo Libro Blanco a lo largo de sus páginas. Por todo lo anterior, tiende a existir cierto consenso entre varios historiadores en orden a que el Libro Blanco no fue sino un texto propagandístico apócrifo, de características panfletarias y cuyo propósito fundamental, según señaláramos arriba, fue justificar el golpe militar, situando para estos efectos el tema de la violencia política ocurrida bajo el gobierno de la UP en un lugar central. El problema que se revela casi de inmediato se refiere a cómo un texto de semejantes características pudo constituirse en la base conceptual y temática para el desarrollo de una explicación, referida al tema de la violencia política, que a la larga se transformaría en hegemónica y trascendería el marco temporal del propio Régimen Militar.

Respecto al texto mismo, cabe precisar que se trata de un trabajo de mediana extensión (casi 270 páginas), en donde el mencionado Plan $\mathrm{Z}$ ocupa apenas seis páginas, sirviendo en realidad como un apéndice del capítulo II, denominado El Autogolpe de la Unidad Popular. El resto de los capítulos ahonda en aquellos elementos que evidenciaban el carácter violentista y armado del régimen unipopular, como por ejemplo la actuación de extranjeros en la política chilena (capítulo III) o el desborde de la constitución y la ley por parte de Allende (capítulo V).

Tras esta primera parte, que se sitúa como una cronología introductoria de la experiencia socialista, el Libro Blanco va mostrando una variada documentación. En primer término, se publica una larga lista de "documentos secretos" que demostrarían, al igual que el Plan Zeta, las oscuras maniobras que ideaba el gobierno de la UP y sus cuadros dirigenciales. En estos primeros textos e imágenes es posible advertir desde la internación de armas cubanas, todas de diverso calibre y operatividad, hasta placas de identificación correspondientes a Carabineros de Chile pero que se encontraban en posesión de miembros de la guardia personal de Allende denominada GAP. Una segunda parte corresponde a documentos emanados del Partido Socialista y que evidenciarían la articulación de diversos planes militares y operativos al interior de esta colectividad, la penetración llevada a cabo al interior de las Fuerzas Armadas, protocolos internos para el fichaje de algunas autoridades civiles y militares y cartillas instructivas para actuar en el marco de la denominada "Alerta Filadelfia": un estado de máxima emergencia que suponía el acuartelamiento general de los partidarios de la UP. La última parte del Libro Blanco es otra recopilación documental, igualmente diversa que la anterior, pero esta vez basándose en textos pertenecientes a diversas instituciones públicas, como la Corte 
Suprema, la Contraloría General de la República y las cámaras legislativas, en donde denunciaban públicamente el camino vertiginoso y virtualmente ilegal que había asumido el gobierno de la UP.

En resumen, el Libro Blanco se divide en dos grandes secciones. La primera parte constituye el marco contextual con el cual se busca destacar el carácter y fisonomía más explícita que asumiera el gobierno socialista, enfatizando en aquellas características que trasuntaban más nítidamente su perfil revolucionario y extremista, cargado, en definitiva, de una retórica y práctica política de corte violentista. La segunda sección constituye el acervo documental del libro, donde se intenta probar a través de un corpus misceláneo de textos tanto los planes de la UP para hacerse con el poder total como las advertencias que distintas organizaciones públicas y personalidades del mundo político hicieron a este respecto. No deja de ser llamativo que la ubicación de los documentos dentro del Libro Blanco siga un orden más o menos premeditado, ajeno a cualquier azar o descuido editorial. Así se complementan tanto documentos oficiales, verídicos en su origen y emanados desde diversas instituciones públicas, como aquellos textos que generan más dudas sobre su veracidad y origen, como fue el caso del Plan Z.

La importancia del Libro Blanco radicaría, a nuestro entender, en que nos proporciona algunos elementos conceptuales y contextuales respecto a la forma con que el mundo militar visualizó entonces el tema de la violencia política bajo la UP. Desde ya este fenómeno es dimensionado, según el texto, a partir de la acción insurgente de una izquierda revolucionaria que había explicitado sin problemas su opción por la violencia y el extremismo. Ante esa amenaza, las Fuerzas Armadas entendieron su rol como esencialmente reactivo, dirigido a poner término a esta espiral de "odio y fanatismo" que se había enquistado en el país. De este modo, la violencia quedaba situada únicamente en el campo contrario, es decir, en el de aquellos que irresponsablemente la decantaron a través de sus retóricas y acciones más representativas. Significativo es que el Libro Blanco utilice una metáfora cromática en su título para entender la compleja coyuntura social y política vivida entonces, pues la acción "salvífica" de unas Fuerzas Armadas albas e intachables, carentes de toda mancha, contrastaría con el oscuro y siniestro proceder de las fuerzas izquierdistas que buscaban no solo controlar el poder, sino también eliminar físicamente a la mayoría de sus oponentes.

Igual de importante que lo anterior es el hecho de que el Libro Blanco constituyó una verdadera matriz de contenidos a partir de la cual otras publicaciones, tanto del mundo civil como militar, abordarían el fenómeno de la violencia política. A decir verdad, el Libro Blanco es la primera versión de la tesis sobre la violencia política en el Chile de los sesenta y setenta. Una versión algo tosca y poco refinada, pero que con el paso del tiempo fue alcanzando mayor envergadura y, por cierto, una proyección historiográfica y política no menor dentro del debate público de los últimos treinta años en Chile. Allí radicaría, pues, uno de sus principales triunfos, a saber; ser la base de una visión cuasi hegemónica y oficial sobre un tema tan complejo y problemático, aún cuando algunos de sus documentos y contenidos más reveladores hayan sido duramente cuestionados en virtud de su real autenticidad y veracidad. No menos trascedente es el hecho de que quien confesase, aunque tardíamente, ser uno de los autores del Libro Blanco -nos referimos a Gonzalo Vial- fuese también el redactor principal del marco contextual del Informe Rettig 
en donde, recordemos, quedó explicitada de modo cabal la tesis sobre la violencia política en el Chile de los sesenta y setenta.

\section{Otras publicaciones del mundo uniformado que abordaron el tema de la violencia política}

Como apuntamos arriba, el Libro Blanco constituyó rápidamente un núcleo basal para que otras publicaciones abordaran el tema de la violencia política. Si bien en algunas ramas de las Fuerzas Armadas el tema ya se había esbozado preliminarmente antes golpe militar, aquel alcanzaría mayor consistencia en el período posterior a dicho evento. Nos interesa revisar aquí algunas de las publicaciones en donde quedaría explicitada esta problemática por parte del mundo uniformado.

La Armada de Chile, a través de su ya tradicional Revista de Marina, abordaría este tema desde aquellos tópicos que le eran más inmediatos y complejos como institución. Recordemos que en los meses previos al golpe militar la Armada fue el escenario de una compleja polémica en torno a la supuesta infiltración de grupos de izquierda en el seno de sus filas a fin de provocar una sublevación generalizada de la tropa. En dicha disputa estuvieron involucrados los parlamentarios Óscar Guillermo Garretón del MAPU, Carlos Altamirano del PS y el secretario general del MIR, Miguel Enríquez, a quienes se acusó, desde el alto mando naval, de promover dicha insubordinación. En su defensa, los dirigentes señalaron que fue un grupo de marinos (de distintas graduaciones) quienes les contactaron a objeto de entregarles diversos antecedentes referidos a los planes golpistas de la oficialidad en contra del gobierno de la Unidad Popular. La polémica fue ardua de principio a fin, pues las autoridades navales pidieron el desafuero de Garretón y Altamirano, al tiempo que procedían a detener y reprimir duramente a aquellos marinos involucrados en estos hechos. Recordemos que toda esta situación acontecía en las semanas previas al golpe militar. ${ }^{20}$

Como es de suponer, la Revista de Marina recogería buena parte de esta sensación ambiente en la mayoría de sus ediciones correspondientes al primer semestre de 1973. En el $\mathrm{N}^{\circ} 3$ correspondiente a los meses de mayo y junio, esta publicación consignó un estratégico artículo de L. F. Bueno Rocero, por entonces teniente de navío de la Armada de España, titulado "La Guerra Cotidiana". En dicho texto se realizaba un examen general en torno a la denominada guerra ideológica, materializada, según el oficial, por activistas tanto nacionales como extranjeros en contra de las instituciones armadas y los valores esenciales de la nacionalidad. Para Bueno Rocero, el propósito de estos sujetos no sería otro que "socavar, debilitar, dividir, azuzar y desmontar las reservas morales de la nación, de la sociedad y del individuo"21, idea que parecía describir a la perfección la compleja situación interna por la que atravesaba tanto el país como la Armada nacional.

En la materialización de estos propósitos, la guerra ideológica seguiría una trayectoria nítida y bastante reconocible según el oficial español. A las situaciones conflictivas de una sociedad polarizada, con sus respectivas víctimas y heridos de

\footnotetext{
20 Uno de los estudios más completos sobre este tema sigue siendo el de Jorge Magasich, Los que dijeron "No". Historia del movimiento de los marinos antigolpistas de 1973, Santiago, Lom, 2008, 2 Vol.

${ }^{21}$ Revista de Marina, Armada de Chile, N³, mayo-junio de 1973, Vol. 90, p. 287.
} 
consideración, le seguiría un periodo generalizado de paros y huelgas. Desde estas últimas nacerán los tumultos, las detenciones y los muertos. Sobre estas víctimas fatales, Bueno Rocero desliza un particular punto de vista: "Muchas autopsias han demostrado, por el calibre de las balas, que los muertos no cayeron abatidos por las armas de la fuerza pública, pero ¿quién va a creer esto?" 22 Ciertamente se trataba de una afirmación que busca revelar el problema de la violencia política como un fenómeno en donde los civiles, y en particular los grupos de izquierda, que se presuponen fuertemente armados bajo la mirada del teniente español, serían los principales responsables de las muertes ocurridas en dichos contextos. En otras palabras, estaríamos en presencia de una situación compleja en donde una parte de la población, aquella más activa y movilizada en pos de la revolución socialista, se encontraría armada y predispuesta al combate.

Tras el golpe militar, las referencias de esta publicación respecto al carácter extremista del depuesto gobierno de la UP no se harían esperar. Resultaba imperativo, en la óptica de esta institución, develar cuanto antes los aspectos más críticos del régimen socialista. En su edición de enero-febrero de 1974, la página editorial de la revista sería enfática en denunciar estos aspectos: "Existía en el país cansancio ante los sucesivos errores, las arbitrariedades e injusticias...el diario desorden [y] los enfrentamientos." 23 Más adelante, este número de la revista publicaría otro texto de un oficial español referente a temas de seguridad nacional. Se trató de Carlos Ariza Miranda, capitán de artillería del Ejército español. En su artículo titulado Meditaciones sobre la Patria y la Defensa, Ariza enfatiza notablemente en las tareas de defensa interna que le corresponden a las fuerzas armadas: "Subrayémoslo: la función militar específica es la guerra, es la lucha por la seguridad colectiva contra enemigos interiores o exteriores. Aunque los entresijos de la lucha y las escaramuzas de la subversión-reversión les enfrente [...] las Fuerzas Armadas están dando la cara por la seguridad común." 24 El énfasis, como se puede apreciar, está puesto nuevamente en la amenaza que representan ciertos sujetos y sectores políticos en particular para la supervivencia de la nación en virtud de sus prácticas y orientaciones ideológicas. En ese marco, la acción de las fuerzas militares debe orientarse a contrarrestar dicha situación, es decir, combatir a dichos actores, de forma terminante y permanente.

No deja de ser sugerente que la Revista de Marina consignara, en el marco del contexto relativo al golpe militar de 1973, las visiones de algunos miembros de las fuerzas armadas españolas en torno a temas de seguridad nacional y combate de aquellas ideologías identificadas como revolucionarias. Como sabemos, España aún se mantenía bajo la férula del régimen franquista, en donde uno de sus elementos identitarios más reconocibles era su marcado anticomunismo. De allí que existiese una sintonía casi natural entre los posicionamientos estratégicos de la oficialidad española y la de sus pares chilenos respecto a los énfasis con que visualizaban su papel dentro de un proceso político e histórico de abierta confrontación en contra del marxismo.

Desde el resto de las instituciones armadas se explicitaron ideas similares respecto de aquellas divulgadas por la Armada y en general por las autoridades militares, situando el tema de la "violencia extremista" como un tópico recurrente y transversal. La Fuerza

\footnotetext{
22 Ibid., p. 289.

${ }^{23}$ Revista de Marina, Armada de Chile, N 1, enero-febrero de 1974, Vol. 91, p. 1.

24 Ibid., p. 28
} 
Aérea de Chile, a través de su revista oficial, hablaría en voz de su Comandante en Jefe, Gustavo Leigh Guzmán. En su edición correspondiente al segundo semestre de 1973, Leigh rubricó la primera editorial que se refería de forma explícita al reciente golpe militar. Como es de suponer, el alto oficial dedicó buena parte de su tribuna a caracterizar negativamente la fallida experiencia socialista de la UP: “A grandes rasgos -decía el uniformado- este ominoso experimento se tradujo en: Infiltración política en las Fuerzas Armadas y Carabineros; Creación de un ejército paralelo, a fin de destruir a los cuerpos armados legales... Internación masiva e ilegal de armas de todos los tipos; La infiltración más alta del mundo." 25 Sintetizando tales planteamientos, bien podría pensarse que antes del 11 de septiembre, tanto las FFAA como el conjunto de la institucionalidad del país, se encontraban virtualmente asediadas y próximas a ser desmanteladas por un enemigo interno estratégicamente emplazado y además fuertemente armado. Tal parecer era subsidiario de la lógica interpretativa con que, recordemos, las FFAA en general intentaron justificar el golpe militar. En la práctica ello suponía caracterizar al depuesto gobierno de la UP como una administración en donde la violencia extremista de sus partidarios definiría la mayor parte de sus cursos de acción. Así, bajo la óptica de Leigh, la violencia política quedaba situada en el terreno de la izquierda, siendo materializada por sus actores y protagonistas más representativos.

La policía uniformada de Carabineros de Chile también articularía el grueso de sus planteamientos en torno al caos que significó el gobierno socialista de la UP, resaltando en el carácter violentista que, en su óptica, aquel representaba. En la revista oficial de la institución, se harían referencias explícitas al accionar de sujetos armados, pertenecientes por supuesto a la izquierda, en la jornada misma del 11 de septiembre: "La fanática acción de los criminales francotiradores, en su mayoría extranjeros, y la posición demencial del Jefe del Gobierno depuesto, tornaron cruenta la acción... la cantidad increíble de armamento automático y pesado en manos de los terroristas obligó a adoptar drásticas medidas para dominar definitivamente la situación." 26 Como vemos, para el mundo uniformado, el tema de las armas en poder de una izquierda supuestamente "enloquecida" por el extremismo fue situado nuevamente como una problemática de primer orden, toda vez que ello significaba reafirmar el carácter violentista del régimen de la Unidad Popular.

En este sentido, los tópicos relativos al decomiso de armamento, con sus respectivos soportes fotográficos, fueron parte sustancial en la conformación de la tesis sobre la violencia política en Chile. En ello operaba la idea de que la justificación del golpe militar no podía expresarse únicamente a través de la palabra escrita, pues era necesario conformar una imagen específica sobre la violencia que la izquierda había generado. Tal imagen se articularía en torno a las armas decomisadas -que demostraban el alto poder de fuego de la izquierda- y a una serie de cuadros, fundamentalmente fotografías de prensa, que mostraban los hechos de violencia callejera más significativos ocurridos bajo la UP. Así se conformaron imágenes concretas de esa violencia. Posiblemente una de las imágenes más icónicas a este respecto correspondió a aquella capturada por un fotógrafo de El Mercurio en el transcurso del primer semestre de 1973 y reproducida posteriormente

${ }_{25}$ Revista de la Fuerza Aérea de Chile. N 129, segundo semestre de 1973, p. 5.

${ }_{26}$ Revista de Carabineros de Chile, N²21, septiembre de 1973, p. 11. 
por diversas publicaciones. En ella se divisa a un sujeto joven ataviado con un pañuelo que cubre su rostro, un casco en donde se leen aparentemente las iniciales de la comunista Brigada Ramona Parra (BRP) y un elemento contundente en cada mano. La actitud del individuo parece indicar que se dispone a golpear a un carabinero que se encuentra frente a él. El policía sólo atina, según se infiere de la fotografía, a protegerse del inminente ataque.

Prácticamente todas las publicaciones mencionadas hasta aquí, incluyeron su respectivo dossier gráfico a la hora de abordar el tema de la violencia política bajo el gobierno de la UP. La Revista de Carabineros no fue la excepción a este respecto. De hecho en su edición de octubre de 1973, se consignó un artículo del teniente coronel Diego Miranda Becerra, titulado "Orden y Patria", el que fue acompañado de la fotografía arriba descrita. ${ }^{27}$ En su edición de noviembre, las imágenes fueron nuevamente parte integrante de los reportajes y notas con que esta publicación denunciaba el carácter violentista del depuesto gobierno. En concreto, allí se publicó una extensa crónica referida al armamento encontrado en los hogares y oficinas pertenecientes a los cuadros dirigenciales de la UP, como Tomás Moro, algunas universidades y domicilios particulares. El total de imágenes llega a veintitrés, las cuales muestran desde fusiles y lanzacohetes hasta machetes, carabinas y otras armas similares. Al decir de esta publicación, la evidencia gráfica no hace sino dar cuenta de la "peligrosa política armamentista del gobierno marxista." 28 Nuevamente, la violencia y el armamentismo quedaban situados únicamente en el terreno de la izquierda.

Una última institución que cabe consignar dentro de esta perspectiva de análisis es la que corresponde a la Policía de Investigaciones. Como sabemos, se trata de una entidad civil que responde a las directrices emanadas directamente desde la Presidencia de la República, por lo que preliminarmente no cabría encasillarla dentro de una óptica uniformada. Sin embargo, tras el golpe militar Investigaciones fue rápidamente intervenida y puesta en manos de oficiales pertenecientes al Ejército, situándose en la jefatura principal, y por espacio de casi siete años, el General de División Ernesto Baeza Michelson. En ese cuadro, es prácticamente un hecho que el énfasis militar respecto al tema de la violencia política bajo la UP, fuese incorporado plenamente a la óptica de la policía civil.

Lo anterior quedaría expresado, por ejemplo, en las notas y reportajes con que una de las publicaciones más importantes de esta institución, DGI Policía Criminal, abordaría el tema. A lo largo de 1974, esta revista incorporó en entregas sucesivas un estudio general realizado por el Teniente Coronel del Ejército Español, Federico Quintero, sobre el empleo de la violencia por parte de la izquierda subversiva. Los dos capítulos más reveladores a este respecto abordaron este fenómeno a partir de dos grandes tópicos. El primero de ellos hacía referencia a la planificación general de la guerrilla urbana en las grandes ciudades, haciendo notar que el espacio selvático o rural que predominó en buena parte de algunos conflictos armados había dado paso, ya a partir de los sesenta, a la "jungla asfáltica", es decir, los emplazamientos urbanos. Este era, pues, el escenario principal para la guerrilla

\footnotetext{
27 Revista de Carabineros de Chile, $\mathrm{N}^{\circ} 222$, octubre de 1973, p. 4.

28 Revista de Carabineros de Chile, № 223, noviembre de 1973, pp. 34 a 40.
} 
subversiva. ${ }^{29}$ Y lo era no sólo por la importancia estratégica que este tipo de centros representaba, sino también por las ventajas comparativas para una actuación encubierta de la guerrilla urbana, con recursos materiales prácticamente ilimitados (domicilios para ocultarse, vías de comunicación, etc.). ${ }^{30}$

El segundo tópico del trabajo de Quintero Morente vino a reforzar los elementos arriba descritos a partir de una caracterización más específica respecto al modo de actuación de la guerrilla urbana. En este sentido, Quintero "revela" varias tácticas utilizadas por estos grupos en aquellos escenarios de enfrentamiento y lucha urbana, como serían el conocimiento previo del lugar, las cadenas telefónicas para acordar puntos de reunión, la utilización de nombres de guerra, etc. ${ }^{31}$ En la parte final de este capítulo se insertó la misma imagen que la Revista de Carabineros incluyera en el artículo del coronel Diego Miranda Becerra en octubre de 1973. Aquella, recordemos, mostraba a un manifestante encubierto y premunido de dos elementos contundentes intentando agredir a un carabinero.

El propósito fundamental de Investigaciones al publicar este trabajo no era, por cierto, prevenir la actuación inminente de una guerrilla urbana en el Chile de 1974. El objetivo consistía más bien en contribuir en la justificación del reciente golpe militar, reforzando uno de los argumentos matrices esgrimidos por las autoridades militares, a saber: la existencia, bajo el gobierno de Allende, de una izquierda fuertemente armada, predispuesta al enfrentamiento y cuyo objetivo central consistía en perpetrar una ofensiva violentísima en contra de sus opositores a fin de alcanzar el poder total.

Los contenidos desarrollados en la publicación arriba descrita constituyen un punto de cierre posible a la hora de sintetizar los lineamientos generales con que el mundo militar dimensionó estas problemáticas. Desde ya cabría señalar que el eje transversal más explícito en todos los trabajos revisados apuntaba a situar el tema de la violencia política como una dinámica propia del mundo de la izquierda. Es decir, que dicho actor fue el que a partir de sus recursos discursivos y factuales abrazó el camino de la violencia y el extremismo para materializar su programa de transición al socialismo. Desde este supuesto se derivó un segundo elemento, a saber, el carácter armado que trasuntó el proyecto de la Unidad Popular, con la consiguiente amenaza que ello representaba para la pervivencia de los actores opuestos a dicho proyecto. De allí que el proceder de las Fuerzas Armadas a partir del 11 de septiembre fuese dimensionada como una acción salvífica que evitó un derramamiento de sangre mayor.

En virtud de lo arriba descrito, los matices y diferencias estratégicas evidenciadas al interior de la Unidad Popular -en donde una de sus tendencias condenaba abiertamente la vía armada y el extremismo- fueron simplemente obviados por la óptica militar en favor de una visión totalizante y maniquea que permitía reforzar la idea en torno al peligro que representaba el conjunto del gobierno socialista.

\footnotetext{
29 Federico Quintero Morente, Empleo de la violencia urbana por la subversión. Capítulo II: Las grandes ciudades. Planificación general de la guerrilla urbana, en DGI Policía Criminal, año II, N 10, julio-agosto de 1974, pp. 21-26.

30 Ibid., p. 22.

31 Federico Quintero Morente, Empleo de la violencia urbana por la subversión. Capítulo III: Modalidades de actuación de la guerrilla urbana, en DGI Policía Criminal, año II, Nº 12, noviembre-diciembre de 1974, pp. 28-29.
} 
Fueron estos elementos enarbolados por el mundo militar los que constituyeron el fermento de la tesis sobre violencia política en el Chile de los sesenta y setenta, explicitada a cabalidad casi veinte años después, en el marco de la Comisión de Verdad y Reconciliación de 1991, pero cuyos fundamentos y utillaje conceptual más importantes ya fue posible apreciar, como hemos visto, apenas ocurrido el golpe militar.

\section{Lecturas subsidiarias. Algunas publicaciones del mundo civil que abordaron tempranamente el tema de la violencia política}

En paralelo a los trabajos y documentos que desde el mundo uniformado explicitaron el tema de la violencia política, algunos civiles abordaron igualmente este tópico a través de diversas publicaciones. Dichos textos, en todo caso, fueron claramente subsidiarios de los énfasis y contenidos con que la perspectiva militar entendía esta problemática. Por tal razón, más que aportar una mirada nueva sobre el tema, resituándolo conceptualmente o abriendo pistas en torno a otras fuentes y metodologías, la mirada del mundo civil fue un reforzamiento, sobre todo discursivo, a lo ya expresado por la óptica castrense. El propósito de esta sección es exponer brevemente algunos de estos trabajos, identificando sus principales puntos de conexión con los énfasis militares ya explicitados.

Dentro de este campo cabe situar en primer lugar el trabajo colectivo liderado por Pablo Baraona, Fuerzas Armadas y Seguridad Nacional, publicado tempranamente a fines de septiembre de 1973.32 Se trata de una serie de artículos que tienen como eje transversal reflexionar sobre el rol de los militares en el marco de la crisis social y política que desembocó en el golpe de estado. En su primera parte, los trabajos abordan aspectos como la vocación militar y el papel de los uniformados en el ordenamiento jurídico chileno. La segunda y tercera parte constituyen el núcleo más crítico respecto al derrocado gobierno de la UP, desarrollando temáticas sobre la crisis económica y alimentaria y la defensa de los grupos sociales frente al gobierno de Allende.

Destacará dentro de este segmento el artículo de Juraj Domic titulado Destrucción de las Fuerzas Armadas por el Partido Comunista. ${ }^{33}$ En dicho texto, Domic describe las intenciones y estrategias que esta colectividad fue desarrollando a objeto de destruir y erosionar la base de sustentación de las Fuerzas Armadas chilenas, entendiendo en este sentido que las acciones del PC chileno están indisolublemente ligadas a las directrices del comunismo internacional. El instrumento catalizador de dicho proceso sería, a su juicio, el poder popular, visualizado por buena parte de los opositores al gobierno de la UP como

\footnotetext{
32 Pablo Baraona, et al, Fuerzas Armadas y Seguridad Nacional, Santiago, Portada, 1973. Baraona, sería un hombre clave del aparato económico del Régimen Militar al presidir el Banco Central y ser posteriormente Ministro de Economía.

33 Juraj Domic, "Destrucción de las Fuerzas Armadas por el Partido Comunista", en Pablo Baraona, et al, Fuerzas Armadas, 237-269. Buena parte de los argumentos desarrollados por Domic en este artículo serían publicados, en formato libro, bajo los siguientes títulos: Modelo Indonesio de Golpe de Estado Comunista, Santiago, Vaitea, 1975 y Destrucción de las Fuerzas Armadas por el Partido Comunista, Santiago, Vaitea, 1975.
} 
un verdadero ejército paralelo. ${ }^{34}$ Adicionalmente, la infiltración comunista dentro de las unidades militares -un tópico ya abordado entonces por el oficial del aire Gustavo Leigh y en general por el alto mando de las FFAA- tenía como propósito fundamental corroer la estructura jerárquica de estas instituciones. Como corolario de lo anterior se observaría un descabezamiento progresivo y posterior neutralización del conjunto de las Fuerzas Armadas. ${ }^{35}$ Tales propósitos, agrega Domic, se vieron detenidos gracias a la intervención militar del 11 de septiembre de 1973.

Desde el periodismo escrito, otro texto abordaría el tema de la violencia política desde una perspectiva igualmente subsidiaria de los énfasis explicitados por la autoridad militar. Nos referimos a Anatomía de un fracaso. La experiencia socialista chilena, escrito por Hernán Millas y publicado en noviembre de 1973.36 Se trata de un trabajo crítico en el abordaje que realiza sobre la Unidad Popular y que abre sus fuegos con una alarmante introducción firmada por Emilio Filippi en donde deja en claro el carácter supuestamente antidemocrático y abusivo del gobierno de Allende. A partir de allí, Millas desarrolla una larga crónica que refiere los episodios más complejos y problemáticos de la experiencia socialista, concluyendo siempre en la culpabilidad de la izquierda respecto de todo lo negativo que aconteciera en el país. En sus primeros capítulos el autor describe un panorama social y político de creciente odio y violencia, soslayando cualquier avance o progreso social materializado por el Ejecutivo. A este clima de virtual enfrentamiento fratricida le siguen, como una consecuencia casi natural, las acciones del gobierno tendientes a hegemonizar su control sobre el agro, la industria nacional y algunos poderes del Estado. Todos estos temas son intercalados a otros según avanzan los años del Chile de la Unidad Popular.

Hacia el cierre, Millas no escatima recursos lingüísticos para abordar nuevamente el fenómeno de la violencia, materializada, a su juicio, por una guerrilla extremista que controlaba cada punto del radio urbano de las principales ciudades del país. ${ }^{37}$ Como es de suponer, en esta parte del relato la ya icónica fotografía del manifestante encapuchado intentando agredir a un carabinero ocupa un lugar destacado -a toda página- dentro del amplio dossier fotográfico que presenta el texto. Igual de importante que lo anterior, es la referencia que se hace al "Plan $Z$ ", tenido como verídico según Millas, el cual arroja luces sobre los planes armados de la izquierda. ${ }^{38}$ Es en estos puntos del relato en donde queda mejor explicitado el carácter subsidiario de la óptica civil respecto a la interpretación uniformada sobre el gobierno de la UP, pues las temáticas y nudos más complejos del proyecto socialista son siempre sintetizados de acuerdo a los marcos conceptuales prefijados por el mundo castrense para referirse a dicho gobierno (guerrilla urbana, extremismo, violencia izquierdista, ejército paralelo, caos, etc.).

Dentro de la óptica civil a la que hacemos mención resulta imposible no detenerse en la mirada del matutino El Mercurio. Nos centraremos en sus rasgos más significativos, reseñando particularmente una serie de crónicas históricas que este medio comenzaría a

\footnotetext{
34 Domic, op. cit, p. 240.

35 Domic, op. cit., p. 251.

36 Hernán Millas, Anatomía de un fracaso. La experiencia socialista chilena, Santiago, Zig-Zag, 1973.

37 Ibid., p. 141.

38 Ibid., pp. 149-153.
} 
publicar el día 20 de septiembre, apenas nueve días después del golpe militar. ${ }^{39}$ Se trató de una síntesis cronológica de los hechos, actuaciones y cambios revolucionarios efectuados por la Unidad Popular en sus casi tres años de existencia, aquilatados todos ellos bajo la pluma siempre implacable y crítica del principal medio opositor al gobierno socialista. La redacción de estas crónicas estuvo a cargo de Teresa Donoso Loero, activista de primera línea en la oposición a Allende y miembro del cuerpo de editores del periódico.

Como era de esperar, el tenor de cada capítulo parece guiarnos hacia el abismo de la decadencia y la desintegración interna, en donde las actuaciones del Ejecutivo y los habituales desbordes de su base militante tenían como único objetivo, según la óptica mercurial, destruir la institucionalidad democrática y avanzar en la construcción de un Estado marxista totalitario. ${ }^{40}$ Sobre los alcances y propósitos de esta reconstrucción es posible señalar que ella se situó como un complemento de los énfasis justificatorios del golpe militar a partir de un trabajo histórico que permitía mantener vivo el recuerdo de una experiencia que aunque derrotada aún resultaba "traumática" para algunos sectores. Se trató de un ejercicio virtualmente terapéutico a objeto de evitar cualquier indicio de amnesia respecto a los puntos críticos del gobierno socialista. Otra posible lectura de este trabajo podría indicarnos que se trata, en el fondo, de una historia de la resistencia civil y de los medios de comunicación al gobierno unipopular, en donde El Mercurio cumpliría, como bien lo explicitó dos años más tarde su Director René Silva Espejo, un rol preponderante en la primera línea de la lucha política. ${ }^{41}$

Para 1974 la experiencia socialista del gobierno de la UP seguía siendo un tópico atractivo para cierto sector de la intelectualidad nacional, sobre todo si el objetivo consistía en exponer el carácter supuestamente totalitario y violentista que bajo esta mirada le era inherente a la izquierda chilena. El escritor y periodista Lautaro Silva publicaría ese año un texto que al igual que el resto de los casos aquí revisados, resultaría plenamente subsidiario de la hegemonía interpretativa -de origen militar- con que se entendía la reciente experiencia de la UP42. Se trata de un texto más amplio que los anteriores, de casi 400 páginas, y que une una crónica histórica de corte más bien personal con la exposición de diversos documentos. En el caso de la crónica, los hechos relatados y las interpretaciones que hace el autor destacan por el lenguaje con que se intenta demonizar a toda la UP y en especial al Presidente Allende. A éste se lo muestra como un sujeto inestable, inclinado en exceso al alcohol y a una "dolce vita nocturna". Más aun se le sindica como autor intelectual del asesinato de su propio edecán naval el comandante Arturo Araya. ${ }^{43}$ Todo lo anterior desfila a lo largo de las páginas sin aportar ninguna fuente o referencia que permita comprobar lo señalado. Respecto a los documentos que

\footnotetext{
${ }^{39}$ El Mercurio, Santiago, 20 de septiembre de 1973, p. 2. El título que encabezó la mayoría de los capítulos fue el de Breve Historia de la Unidad Popular, adicionando un subtítulo que refería el contenido específico que se abordaría en cada edición.

40 Significativo a este respecto fueron algunos capítulos como "Ofensiva para robustecer la prensa marxista en los primeros meses de la Unidad Popular" El Mercurio, Santiago, 21 de septiembre de 1973, 2; "Víctimas del terror marxista", El Mercurio, Santiago, 24 de septiembre de 1973, 2; "15 días de pesadillas y crímenes", El Mercurio, Santiago, 27 de septiembre de 1973, 2; "Los extremistas en el campo", El Mercurio, Santiago, 1 de octubre de 1973, p. 18.

${ }^{41}$ René Silva Espejo, "El Mercurio" y su lucha con el marxismo, Santiago, Editora Nacional Gabriela Mistral, 1975.

42 Lautaro Silva, Allende: El fin de una aventura, Santiago, Ediciones Patria Nueva, 1974.

${ }^{43} \mathrm{Ibid}, \mathrm{p} .347$.
} 
consigna este texto, estos corresponden a diversos orígenes. Una parte significativa de ellos, los referidos al ya famoso Plan Z, son copiados desde el Libro Blanco ${ }^{44}$, mientras que otros registros corresponden a información de prensa y a los primeros documentos que emanaron desde la Junta Militar de Gobierno tras el golpe ${ }^{45}$. En su afán por demostrar el carácter subversivo y extremista del gobierno de Allende la prosa de este texto se diluye en un mar de acusaciones y suposiciones personales del autor que no encuentran un respaldo sólido en algún marco documental que vaya más allá del cuestionado Libro Blanco o de la información oficial que emanaba desde la Dictadura. Se trata más bien de un libro propagandístico, muy en sintonía con otras publicaciones del periodo, y que refleja el temor casi esquizofrénico de su autor por el socialismo y sus representantes.

Al año siguiente, 1975, los énfasis y documentación aportada por el Libro Blanco todavía influían en algunos rincones. Plenamente subsidiario de esta lógica interpretativa fue el texto de Pedro Ovalle, publicado en España y en donde se reactualizaba la importancia del denominado Plan Z.46 Tratando de aportar un nueva mirada sobre este tema, el autor vincula dicho plan a una supuesta intervención soviética. Sin embargo, en la práctica Ovalle no entrega ninguna prueba documental al respecto, su libro no tiene bibliografía ni notas a pie de página. No posee, en definitiva, un aparato crítico que lo sustente. Su orientación es claramente propagandística, pero consideramos pertinente consignarlo en este espacio a fin de retratar la influencia que seguía teniendo la óptica militar a través del Libro Blanco.

Otro ejemplo que se ubica en esta misma dirección, es decir como publicaciones tributarias de la lógica interpretativa del mundo uniformado, es posible encontrarla en el texto de Suzanne Labin, Chile: el crimen de resistir. ${ }^{47} \mathrm{Su}$ objetivo es desacreditar las acusaciones realizadas en contra del Régimen Militar por el tema de las violaciones a los derechos humanos, planteando a este respecto una defensa irrestricta del accionar uniformado que "salvó a Chile del comunismo." 48 Tal proceder implicaba, a juicio de Labin, reconstruir los episodios más oscuros de la Unidad Popular, a fin de contrastarlos respecto del proceder patriótico de las Fuerzas Armadas que evitaron la instauración de un proyecto totalitario. En este sentido, la autora centra su análisis en el tema de la violencia política, situándola -al igual que el resto de los autores aquí consignados- como una expresión característica y casi natural de una izquierda fuertemente armada y predispuesta a la eliminación física de sus oponentes. El capítulo donde aborda esta temática ("Vía violenta hacia el socialismo") se apoya documentalmente en el Libro Blanco y en publicaciones periódicas como El Mercurio.49 Así, las opciones metodológicas de Labin -a las que se agrega su experiencia personal a través de diversos viajes que realizó a Chile en esos años- sintetizan un pensamiento plenamente coherente y subsidiario a la

44 Ibid, capítulo XI, pp. 277-323.

45 Ibid, pp. 379-382.

46 Pedro Ovalle, Libro Negro del atentado marxista-leninista en Chile. Los orígenes y las últimas consecuencias del "Plan Z", Madrid, Speiro, 1975.

47 Suzanne Labin, Chile: el crimen de resistir, Santiago, Ediciones Semblanza, s/f. Por las temáticas abordadas y algunas escasas referencias de contexto creemos que el libro de Labin fue escrito hacia finales de la década del setenta.

48 Ibid., pp. 300-301.

49 Ibid., pp. 91-112. 
lógica interpretativa del mundo militar. Es decir, el accionar de las Fuerzas Armadas se comprende en toda su dimensión, y por ende se justifica, si se reconoce el contexto previo al 11 de septiembre de 1973, en donde el gobierno de la UP, al decir de esta mirada, transitaba por el sendero de la ilegalidad y el extremismo y cuya base militante más activa se encontraba fuertemente armada. Siguiendo esta línea de análisis, los militares actuaron reactivamente frente a un contexto específico que fue detonado por el accionar irresponsable de otros actores.

¿Tuvo alguna originalidad entonces la perspectiva civil respecto al tema de la violencia? En las obras arriba reseñadas observamos una mirada plenamente dependiente y, como ya indicamos, subsidiaria de los énfasis con que el mundo militar entendió el proyecto político de la Unidad Popular y posteriormente su propio accionar a objeto de derrocar dicho gobierno. En tal sentido, no existió mayor originalidad, ni metodológica ni temática, del mundo civil para abordar este fenómeno. Esta perspectiva actuó más bien como una caja de resonancia de los acordes compuestos y ejecutados por las autoridades militares, trascendiendo más allá del propio gobierno militar y situándose en pleno contexto de la transición a la democracia como una explicación coherente y hegemónica a la hora de entender el problema de la violencia política en Chile.

\section{Conclusiones}

Al comenzar la década del noventa en Chile, y con ella la transición, la tesis sobre violencia política en las décadas del sesenta y setenta, en tanto factor explicativo y justificatorio del golpe militar, terminó por alcanzar su estatus hegemónico dentro del debate público. Su medio de exposición más relevante fue a través del Informe Rettig de la Comisión Nacional de Verdad y Reconciliación, organismo que buscaba, recordemos, indagar en las zonas más grises de las violaciones de los derechos humanos ocurridas en Dictadura. A pesar de los objetivos de esta comisión, la mencionada tesis logró insertarse con maestría dentro de dicho texto de la mano del historiador Gonzalo Vial, situándose como el eje articulador de lo que se llamó el contexto previo al 11 de septiembre. Dicha etapa resultaba imposible de desconocer si se quería comprender a cabalidad los últimos veinticinco años de nuestra historia con una de sus problemáticas más agudas plenamente vigente.

La importancia de este acontecimiento radica en que la tesis sobre violencia política no puede visualizarse como un producto de la transición, pues sus bases conceptuales y temáticas más relevantes, según hemos visto, habían sido elaboradas apenas ocurrido el golpe militar. Se trató entonces de una tesis pensada y articulada desde el mundo militar, utilizada primeramente para justificar el golpe de estado y luego, al comenzar los noventa, para ser parte sustancial de la explicación oficial sobre las causas que originaron el quiebre de la democracia y decantaron las violaciones a los derechos humanos. En este tránsito desde los setenta hasta el periodo de la transición, Gonzalo Vial cumplió un rol fundamental al situarse como el redactor principal de los documentos oficiales -como el Libro Blanco y el marco histórico del Informe Rettig- que explicitaron dichas temáticas. En el caso del primero de esos textos, Vial fue simplemente un amanuense de los dictados militares referentes al tema de la violencia. Él mismo ha confesado esta situación al señalar 
que el proceso de escritura del Libro Blanco fue efectuado a partir de los documentos que las autoridades uniformadas le mostraron, a él y otras personas hasta ahora desconocidas, encargándole la redacción de un texto que divulgara dichos papeles y fijara una explicación oficial al respecto. ${ }^{50}$ En el marco contextual del Informe Rettig existe posiblemente una elaboración más propia de parte de Vial, no obstante el escenario descrito en relación a la situación social y política antes del 11 de septiembre es igualmente subsidiario de aquellos lineamientos matrices explicitados por el mundo castrense en 1973.

Tal interpretación, denominada en este artículo como perspectiva militar, estaba articulada en torno a tres líneas de análisis respecto a la izquierda chilena en general y al gobierno de la Unidad Popular en particular. La primera de ellas, insertaba los proyectos de cambio estructural de mediados del siglo XX dentro de una fase mundial de polarización ideológica entre dos bandos representados por Estados Unidos y la Unión Soviética, con sus respectivos bloques y alianzas de apoyo. La pugna verificada entre ambas alternativas tuvo como consecuencia directa un proceso gradual de sobreideologización en diversos actores, tanto regionales como nacionales y pertenecientes únicamente a la izquierda los cuales, según esta visión, vieron en la vía armada un camino factible y legítimo para materializar sus propuestas de acción política. La segunda línea de análisis desarrollada por la perspectiva militar, visualizaba al gobierno de la UP como una experiencia que transitó desde un comienzo por el camino armado, revelándose como un proyecto abiertamente rupturista, contrario a la nacionalidad y enfocado en derribar la institucionalidad existente a objeto de instaurar un estado marxista totalitario. La tercera línea de análisis, explicitada como una de las más importantes por buena parte de la bibliografía revisada, sostenía que la violencia resultaba consustancial a la izquierda chilena, cuyas prácticas, tanto factuales como discursivas, adherían casi naturalmente a una metodología violenta y extremista.

Fueron, pues, estos énfasis los que resultaron transversales a casi cualquier lectura que adhiriera tanto implícita como explícitamente a la tesis sobre violencia política en el Chile de los sesenta y setenta. ${ }^{51}$ En virtud de ello la pregunta más apremiante al respecto es por qué dicha tesis logró posicionarse como una explicación consensualmente hegemónica en el país, llegando incluso a ser parte sustancial del Informe Rettig.

Una explicación posible implica considerar los espacios temporales en que dicha tesis se divulgó. Tras el golpe militar, el campo comunicacional fue rápidamente copado por las autoridades uniformadas, por lo que cualquier información se encontraba mediatizada por los énfasis e intereses de este sector. De este modo, la publicación del Libro Blanco no solo se situó como la explicación oficial del golpe militar, sino que también ella no pudo ser rebatida ni menos revisada críticamente. Décadas después, al iniciarse la transición bajo la lógica de la salida pactada, en donde los militares seguían siendo un actor preponderante, tampoco hubo voces críticas que cuestionaran los énfasis de dicha explicación. ${ }^{52}$ Adicionalmente, los actores de izquierda que personificaban buena parte de

\footnotetext{
50 Ver nota 3.

51 Trascendiendo incluso la década del noventa, algunos autores seguían adscribiendo a esta línea de análisis. Véase, por ejemplo, Enrique Brahm, "Retórica violentista de izquierda y miedo a la revolución en Chile", Bicentenario, Vol. 2, N² (2003).

52 Esto pudo revelarse, por ejemplo, en algunos encuentros académicos en donde predominaban las visiones más afines a la lógica de la transición. Una de estas reuniones fue organizada por la Universidad Católica de
} 
las conductas violentistas explicitadas en la mencionada tesis se encontraban, bajo la época de la transición, o en posiciones relativamente marginales dentro del escenario público, o bien, insertados dentro de la coalición gobernante gracias al perfil renovado y liberal que habían asumido sus trayectorias personales. Desde tales posiciones de poder, claro está, algunas de estas figuras no cuestionarían lo esencial de lo descrito por la mencionada tesis. Más bien asumirían que su pasado político, al calor de la experiencia socialista de la UP, estuvo efectivamente teñido por la violencia y el extremismo. De tal manera entonces, buena parte de la clase política del periodo transicional fue renuente a cualquier revisionismo histórico que implicara alterar los puntos nodales explicitados por el Informe Rettig respecto a las causas del quiebre de la democracia en 1973, en donde el tema de la violencia izquierdista ocupaba un lugar central.

Conviene recordar asimismo, que el tema de la violencia ya había sido un tópico polémico en el marco de la década de los ochenta, en donde un sector de la oposición a la Dictadura (aquella denominada inicialmente como Alianza Democrática y que luego se transformaría en la Concertación de Partidos por la Democracia) rechazó en su momento cualquier estrategia o curso de acción violento para oponerse al régimen y lograr su caída, propiciando, por el contrario, una salida consensuada e institucional entre ambas partes. Ello significó, en la práctica, marginar de las negociaciones y del espacio político transicional que comenzaba a abrirse en la segunda mitad de los ochenta a aquellos actores que habían promovido una vía confrontacional contra Pinochet. La violencia política explicitada por ciertos grupos quedaba resituada entonces, desde la clase dirigente concertacionista, como una conducta extremista, virtualmente anómica, y que alteraba los equilibrios institucionales y la paz social, cuestión que le restaba cualquier grado de legitimidad y operatividad. No sería extraño, en este contexto, que dichos grupos dirigentes, imbuidos de una lógica claramente crítica respecto de la violencia política -a la cual habían logrado marginar del debate político transicional- asumieran sin mayores cuestionamientos la argumentación contextual incluida en el Informe Rettig referida al ciclo de violencia escenificado antes del golpe militar de 1973 por parte de la izquierda. En otras palabras, existía plena concordancia entre una estrategia crítica de la violencia política surgida en los ochenta con una postura anuente respecto de aquella interpretación que veía en las conductas y discursos más extremos y violentos de la izquierda revolucionaria chilena una de las cusas principales del quiebre democrático.

Cabría precisar también que esta tesis sentó un lugar común referente al tema que serviría de sustento para seguir profundizando en él por parte de nuevos investigadores, quienes asumirían acríticamente sus principales postulados. Desde esta perspectiva, el tema de la violencia política perpetrada por la izquierda de los sesenta y setenta volvía a ser un tópico de creciente interés a lo largo de casi toda la década del noventa, e incluso, en los primeros años de la centuria siguiente. De algún modo, esta situación se conectaría con otra de mayor complejidad referida a los silencios de la izquierda, sobre todo aquella asentada en el mundo académico, a la hora de abordar los temas de violencia en el periodo

Chile en 1991 cuyo propósito fue examinar las causas del quiebre de la democracia en 1973. Al año siguiente las ponencias allí presentadas fueron compiladas en el libro editado por Matías Tagle, La crisis de la democracia en Chile. Antecedentes y causas, Santiago, Andrés Bello, 1992. 
de la Unidad Popular, 53 escapando por cierto de los enfoques maniqueos e incompletos desarrollados, por ejemplo, en el Libro Blanco. Hasta ahora, la discusión parece haberse sintetizado entre una postura negacionista del fenómeno, es decir, que la violencia política no existió bajo la UP54, y otra más bien renuente a tocar el tema. Con todo se trata de una problemática incómodamente abierta en el espacio de los estudios historiográficos, que tendrá que esperar posiblemente por nuevas generaciones de investigadores ${ }^{55}$ para ser tratadas en su propia extensión y complejidad.

\section{Bibliografía}

\section{Impresos}

\section{Libros}

Arancibia, Patricia. Los orígenes de la violencia politica en Chile. 1960-1973. Santiago: Universidad Finis Terrae- Instituto Libertad y Desarrollo, 2001.

Arancibia, Patricia; Aylwin, María; Reyes, Soledad. Los hechos de violencia en Chile: del discurso a la acción. Santiago: Universidad Finis Terrae-Instituto Libertad y Desarrollo, 2003.

\footnotetext{
53 En 1999, académicos de distintas universidades redactaron y firmaron un Manifiesto de Historiadores, en donde se respondía a los planteamientos esgrimidos tanto por Augusto Pinochet en su Carta a los chilenos -escrita desde su lugar de detención en Londres- como a los tópicos abordados por Gonzalo Vial en sus columnas y fascículos publicados en el periódico La Segunda. Pinochet y Vial esgrimían, en sus respectivos textos, que una de las causas fundamentales de la crisis institucional de 1973 había sido el proceso de polarización política verificado al interior de la izquierda y agudizado bajo la Unidad Popular. Se trataba por cierto de una reafirmación de la tesis sobre violencia política de los sesenta y setenta. El mencionado Manifiesto sostuvo que los procesos de radicalización política obedecían a diversos factores, entre ellos la estagnación económica, la crisis social, al fracaso de los gobiernos radicales, etc. Por lo que no podía atribuirse al guevarismo -como sí sostenía Vial- ser el factor detonante de dicha polarización. Si bien se trató de un documento importante que logró abrir cierto debate -llegando a redactarse inclusive otros dos manifiestos más- lo cierto es que no supo explicitar cómo abordar el fenómeno de la violencia política antes de 1973, es decir, desde qué perspectivas metodológicas o conceptuales se podía iniciar un primer acercamiento a dicho fenómeno. De hecho, visualiza esta problemática y la resitúa en el campo contrario, es decir, como una estrategia de las fuerzas reaccionarias a la Unidad Popular. Véase Manifiesto de Historiadores (Santiago, enero de 1999). Recuperado de http://www.archivochile.com/Ceme/recup_memoria/cemememo0003.pdf acceso, 21.09.2017.

54 Esta postura ha sido asumida por Luis Corvalán, Del anticapitalismo al neoliberalismo en Chile, Santiago, Sudamericana, 2001, 25-27, y Manuel Antonio Garretón, "Memorias en disputa: consenso fáctico y lucha de contenidos", en, Andrés Estefane y Gonzalo Bustamante [comp.], La agonía de la convivencia. Violencia política, historia y memoria, Santiago, RIL, 2014, 153-160.

55 Un primer avance puede observarse en los trabajos de Danny Monsalvez referidos a la historia reciente de nuestro país. Véase al respecto, "El debate historiográfico y político sobre los orígenes de la violencia política en la historia reciente de Chile (1960-1990)", Sociedad y Discurso, № 23 (2013), pp. 104-125. También podría incluirse el novedoso trabajo de Pía Montalva, Tejidos Blandos. Indumentaria y Violencia Política en Chile, 19731990, Santiago, FCE, 2013, aunque su análisis, como se puede advertir, se centra exclusivamente en el periodo de la Dictadura Militar. Una perspectiva que visualiza el tema de la violencia política, en el largo periodo 19701991, desde el ámbito del espacio público y la disputa por la memoria en los espacios urbanos es posible encontrar en Carolina Aguilera-Inzunza. "Víctimas y mártires de la violencia política reciente en Chile ¿Una memoria en disputa?", AUS, Nº 20 (2016) s/p [Revista electrónica sin formato PDF]
} 
Baraona, Pablo, et al. Fuerzas Armadas y Seguridad Nacional. Santiago: Portada, 1973. Contreras, Manuel. La verdad histórica. El Ejército Guerrillero. Santiago: Encina, 2000.

Corvalán, Luis. Del anticapitalismo al neoliberalismo en Chile. Santiago: Sudamericana,

Domic, Juraj. Modelo Indonesio de Golpe de Estado Comunista. Santiago: Vaitea, 1975.

Domic, Juraj. Destrucción de las Fuerzas Armadas por el Partido Comunista. Santiago: Vaitea, 1975.

Estefane, Andrés, Bustamante, Gonzalo. [comp.]. La agonía de la convivencia. Violencia política, historia y memoria. Santiago: RIL, 2014.

Ibáñez, Adolfo. Abrazado por la revolución: ideología y totalitarismo en Chile. 1960-1973. Santiago: Biblioteca Americana, 2004.

Labin, Suzanne. Chile: el crimen de resistir. Santiago: Ediciones Semblanza, s/d

León, Alberto. Tiempo Rojo y el alzamiento del blindado, Santiago: 1999.

Magasich, Jorge. Los que dijeron "No". Historia del movimiento de los marinos antigolpistas de 1973. Santiago: Lom, 2008. 2 Vol.

Millas, Hernán. Anatomía de un fracaso. La experiencia socialista chilena. Santiago: ZigZag, 1973.

Molina, Carlos. Balart, Francisco, La violencia política en Chile. Santiago: Biblioteca Militar, 1999.

Montalva, Pía. Tejidos Blandos. Indumentaria y Violencia Política en Chile, 1973-1990. Santiago: FCE, 2013.

Ovalle, Pedro. Libro Negro del atentado marxista-leninista en Chile. Los orígenes y las últimas consecuencias del "Plan Z". Madrid: Speiro, 1975.

Salazar, Gabriel. La violencia politica popular en las "Grandes Alamedas". La violencia en Chile 1947-1987. Santiago: Lom, 2006.

Silva, Lautaro. Allende: El fin de una aventura, Santiago: Ediciones Patria Nueva, 1974.

Silva, René. El Mercurio" y su lucha con el marxismo. Santiago: Editora Nacional Gabriela Mistral, 1975.

Tagle, Matías. La crisis de la democracia en Chile. Antecedentes y causas. Santiago: Andrés Bello, 1992.

\section{Artículos}

Aguilera-Inzunza, Carolina. "Víctimas y mártires de la violencia política reciente en Chile ¿Una memoria en disputa?". En AUS, N² 20 (2016) s/p.

Brahm, Enrique. "Retórica violentista de izquierda y miedo a la revolución en Chile". En Bicentenario, Vol. 2, № 2 (2003)137-153.

Jelin, Elizabeth. "Militantes y combatientes en la historia de las memorias: silencios, denuncias y reivindicaciones", Meridional, N 1 (2013). 77-97.

Monsalvez, Danny. "El debate historiográfico y político sobre los orígenes de la violencia política en la historia reciente de Chile (1960-1990)". En Sociedad y Discurso, № 23 (2013). 104-125.

Piñera, José. "Nunca Más. Un ensayo sobre el quiebre de la democracia en Chile". El Mercurio, Santiago, 24 de agosto de 2003, Cuerpo de Reportajes, 11-13.

\section{Revistas y periódicos}


DGI Policía Criminal, 1974.

El Mercurio, 1973

La Segunda, 1999.

Revista Aquí Está, 1973.

Revista de Carabineros de Chile, 1973.

Revista de la Fuerza Aérea de Chile, 1973.

Revista de Marina, 1973 - 1974.

Fuentes documentales:

Eudeba, 1986.

Comisión Nacional sobre la Desaparición de Personas, Nunca Más, Buenos Aires,

Gobierno de Chile, Hacia el reencuentro de todos los chilenos. Acuerdo de la Mesa de Diálogo., 2000.

Informe de la Comisión Nacional de Verdad y Reconciliación. Santiago, 1991, 3 Vol.

Secretaría General de Gobierno, Libro Blanco del cambio de gobierno en Chile. 11 de septiembre de 1973. Editorial Lord Cochrane, Santiago, 1973. [2a edición].

\section{Fuentes electrónicas:}

Demassi, Carlos. “Ante la teoría de los dos demonios ¿cuáles dos demonios?” columna de opinión publicada en:

http:// www.paginadigital.com.ar/articulos/2003/2003quint/noticias18/1204711-7.asp.

Manifiesto de Historiadores, Santiago, enero de 1999.

Recuperado de

http://www.archivochile.com/Ceme/recup_memoria/cemememo0003.pdf 